\title{
Gross anatomy of the narial and labial musculatures of one humped Camel (Camelus dromedarius)
}

\author{
ADAM, Z. A., AWAAD, A. S., TAWFIEK, M. G. * and IBRAHIM, A. L. H. \\ Department of Anatomy and Embryology, Faculty of Veterinary Medicine, Beni-Suef University, Beni-Suef 62511, Egypt \\ *E-mail: mgtawfiek@yahoo.com
}

\begin{abstract}
Introduction: The objective of this study was to clarify the anatomy of the narial and labial musculatures of the one-humped camel (Camelus dromedarius) and their nerve supply. Materials and Methods: Sixteen head specimens from adult and symptomatically healthy camels of both sexes were used. The muscles of the nostrils and lips were carefully dissected and illustrated to demonstrate their origin, insertion and relations. The nerves in this area were also dissected to show their branches and distribution. Results: The dissection of these regions revealed that their muscles were arranged in three layers; the superficial layer included M. dilator naris apicalis, M. dilator naris medialis and M. levator nasolabialis, the middle layer was formed of maxillo-labial group of muscles (M. levator labii superioris, M. dilator naris lateralis and M. depressor labii superioris) and the deep layer was formed by M. lateralis nasi. Moreover, the lips had M. orbicularis oris, M. incisivus superioris, M. incisivus inferioris and M. mentalis, however, the M. depressor labii inferioris was absent in the animal under investigation. The muscles of nostrils and lips were innervated by N. trigeminus (V) and N. facialis (VII). Conclusion: The arrangement of the narial and labial muscles is unique and may relate to its living conditions of frequent sand-storms and direct sun rays, where the camel is the only domesticated animal known for its ability to close its nostril.
\end{abstract}

Keywords: camel, anatomy, nostril, lips, muscles, nerves.

\section{Introduction}

One-humped camel (Camelus dromedarius) is found in Egypt, Iran, Iraq, Saudi Arabia, Sudan, North Africa, Somaliland, India and many other countries (MONFARED, 2013). This animal adapted to the rigorous climate of the desert where it is subjected to high temperature and direct sun rays (SADEGH, SHADKHAST, SHARIFI et al., 2007). In the last decade of camel domestication, it is used as an essential source of milk, meat, hide and hair especially in developing countries (AHMAD, YAQOOP, HASHMI et al., 2010; OUAJD and KAMEL, 2009). Additionally, a little is known about the anatomy of the camel narial and labial musculatures (ALI MA KHIDR and EL-HAGRI, 1979; ESHRA and BADAWY, 2014; SMUTS and BEZUIDENHOUT, 1987). The camel is the only domesticated animal known for its ability to close its nostril (ESHRA and BADAWY, 2014; HAFEZ, 1968). Moreover, Hafez (1968) added that the nasal region has a special importance in racing camels, as they sometimes need a surgical operation for widening their nasal aperture, so the anatomy of this region should be studied in details to avoid the destruction of the nasal cartilages or other related structures during such operations. The lips of the camel are extremely mobile, and covered by soft and tactile hairs, the upper lip is bifid by a deep philtrum (HAFEZ, 1968; SMUTS and BEZUIDENHOUT, 1987). Even though, the muscles and nerves of the nostrils and lips of the dromedary camel had been described by (ESHRA and BADAWY, 2014; KHIDR, 1978; SMUTS and BEZUIDENHOUT, 1987), more details on the architecture and arrangement of these muscles and their nerve supply are still needed. This will provide a morphological basis for further research on the comparative myology and neuroanatomy of these important regions of the one-humped camel. Therefore, the present study aimed to investigate the origin, insertion and structure of the narial and labial muscles of the one-humped camel and their nerve supply.

\section{Materials and Methods}

The present work was carried out on sixteen heads of adult and symptomatically healthy one-humped camels (Camelus dromedarius) of both sexes. The specimens were brought from the local abattoir at Beni-Suef Governorate for dissection purposes in Anatomy laboratory, Beni-Suef University, Egypt. The heads were severed at the atlanto-axial joint and were embalmed according to Hildebrand (1968). Where thorough washing of the common carotid arteries using warm normal saline solution to remove excessive blood. The arteries were injected with embalming fluid (about $2 \%$ full strength formalin $40 \%, 2 \%$ concentrated liquid phenol, about $6 \%$ glycerin, about $20 \%$ alcohol strength $95 \%$, and about $70 \%$ water). The specimens were kept in this embalming fluid for one week prior to dissection. Then careful dissection was done to the labial and narial regions to demonstrate their musculatures and nerves. Nomenclatures used in this study were adopted according to Nomina Anatomica Veterinaria (INTERNATIONAL..., 2012) and the available literatures.

\section{Results}

The nostrils of the dromedary camel were a slit-like with longitudinal axis oblique rostro-medially (Figures 1-3). The lips were extremely mobile; the upper lip was bifid in its centre with 


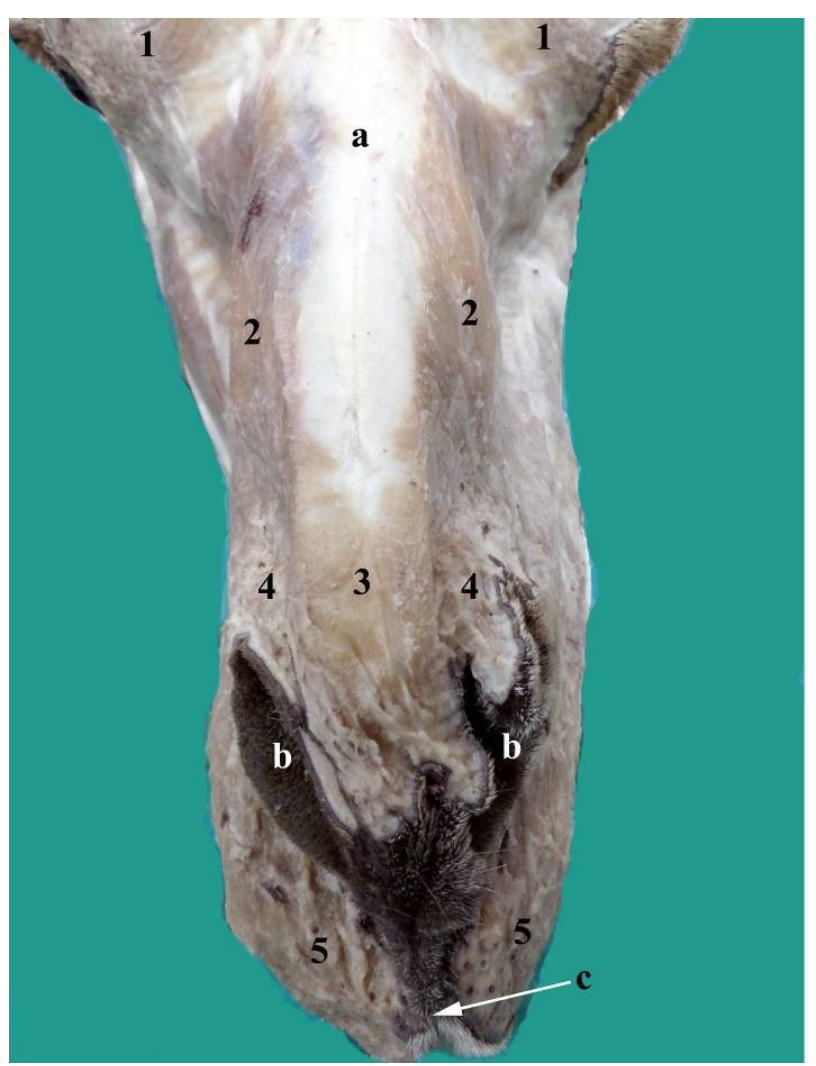

Figure 1. A Photograph showing the muscles of the lips and nostrils of the one-humped camel (Dorsal view): a- Nasal bone, b- Nostrils, c- Median labial fissure. 1- M. frontalis, 2- M. levator nasolabialis, 3- M. dilator naris apicalis, 4- M. dilator naris medialis, 5- M. orbicularis oris.

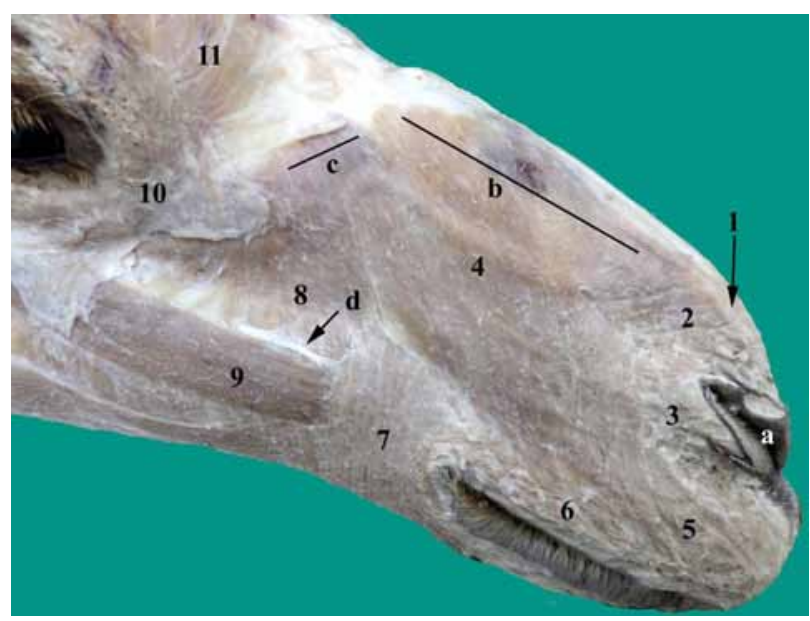

Figure 2. A Photograph showing the muscles of the lips and nostrils of the one-humped camel (Right side). a- Nostril, b- Dorsal origin of M. levator nasolabialis, $\mathrm{c}$ - ventral origin of M. levator nasolabialis, d- R. dorsalis of N. buccalis. 1- M. dilator naris apicalis, 2- M. dilator naris medialis, 3- Termination of $\mathrm{Mm}$. levator nasolabialis, caninus and dilator naris lateralis, 4- M. levator nasolabialis, 5- pars labialis of M. orbicularis, 6- Pars marginalis of M. orbicularis oris, 7- Pars buccalis of M. buccinators, 8- M. malaris, 9- M. zygomaticus, 10- M. orbicularis oculi, 11- M. frontalis. deep philtrum forming the median labial fissure (Figure 1), while the lower one tended to be pendulous (Figure 5). The muscles of the nostrils and lips were arranged in three layers; superficial layer (M. dilator naris apicalis, M. dilator naris medialis and $M$. levator nasolabialis), middle layer was formed of maxillo-labial group of muscles (M. levator labii superioris, $\mathrm{M}$. dilator naris lateralis and $\mathrm{M}$. depressor labii superioris) and deep layer (M. lateralis nasi). Moreover, the lips had $M$. orbicularis oris, $M$. incisivus superioris, $M$. incisivus inferioris and M. mentalis.

The superficial layer of the narial and labial muscles consisted of three muscles were; $M$. dilator naris apicalis, M. dilator naris medialis and M. levator nasolabialis.

1.M. Dilator Naris Aplicalis (M. Transversus Nasi) and M. Dilator Naris Medialis:

The dilator naris aplicalis and dilator naris medialis muscles (Figure 1/3.4) were present superficially under the skin of the nasal region. They originated by a common tendon from the fascia which covered the dorsal parietal nasal cartilage in common with the dorsal origin of the M. levator nasolabialis with no line of demarcation. The muscle fibers of the M. dilator naris aplicalis of both sides were fused together, directed rostroventrally and inserted into the dorsal aspect of the nostril (Figure 1/3). While, the muscle fibers of the $\mathrm{M}$. dilator naris medialis directed caudoventrally and inserted into the rostromedial aspect of the wing of the nostril (Figures 1/4,2/2). The caudal fibers of these two muscles were fused with $\mathrm{M}$. levator nasolabialis (Figure $2 / 2,4$ ). At the level of the caudal part of the wing of the nostril, the ventral fibers of $\mathrm{M}$. dilator naris medialis were continuous with those of $\mathrm{M}$. levator nasolabialis, $\mathrm{M}$. caninus and $M$. lateralis nasi (Figure $2 / 2,3$ ).

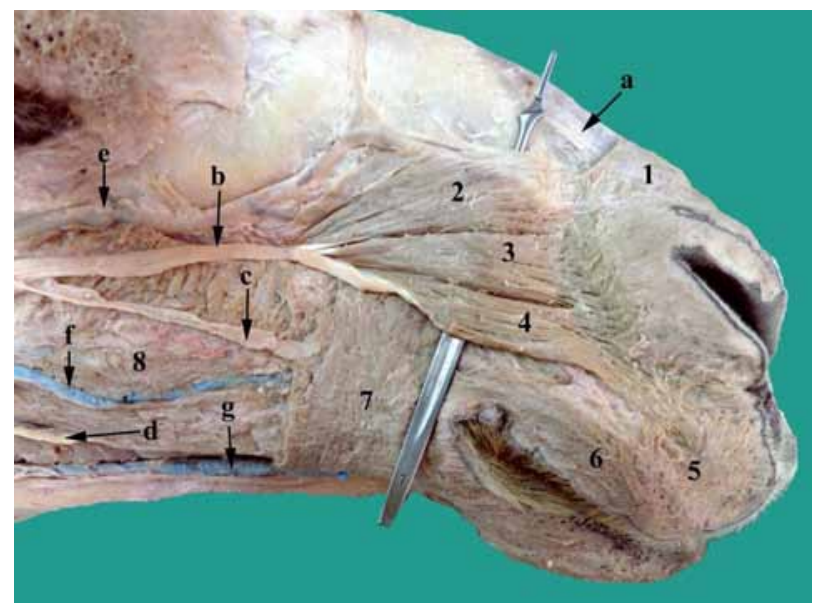

Figure 3. A Photograph showing the muscles of the lips and nostrils of the one-humped camel after removal of $\mathrm{Mm}$. levator nasolabialis and malaris (Right side). a- N. nasalis externus, b- N. buccalis dorsalis, $\mathrm{c}-\mathrm{R}$. dorsalis of $\mathrm{N}$. buccalis, $\mathrm{d}-\mathrm{R}$. ventralis of $\mathrm{N}$. buccalis, e- V. facialis, $\mathrm{f}-\mathrm{V}$. buccalis superficialis, $\mathrm{g}-\mathrm{V}$. labialis inferior superficialis. 1- M. dilator naris medialis, 2- M. levator labii superioris, 3- M. dilator naris lateralis, 4- M. depressor labii superioris, 5- Pars labialis of M. orbicularis oris, 6- Pars marginalis of M. orbicularis oris, 7- Pars buccalis of M. buccinators, 8- Pars molaris of $\mathrm{M}$. buccinators. 


\section{M. Levator Nasolabialis:}

The M. levator nasolabialis was a broad and subcutaneously situated in an area extended rostral to the orbit till the nostril and maxillary lip (Figure 2/4). This muscle appeared to have

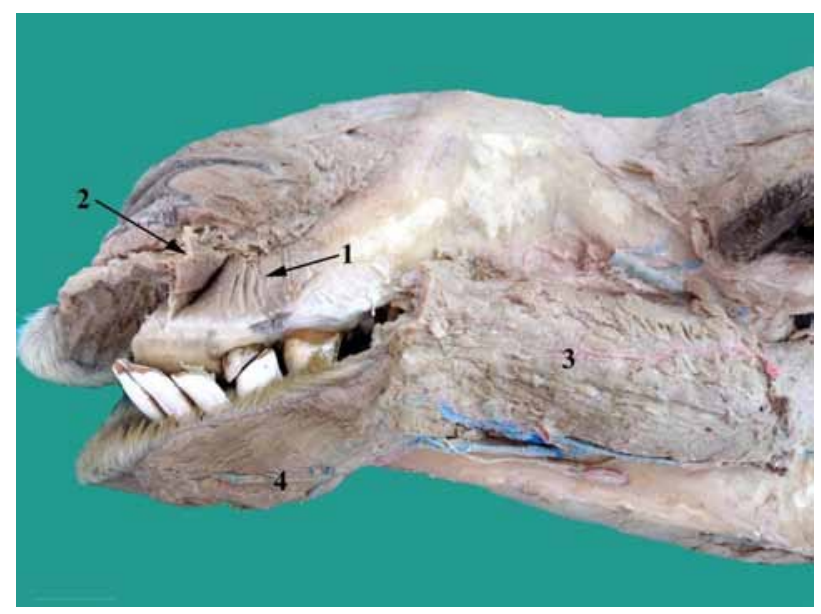

Figure 4. Photograph showing the $M$. lateralis nasi of the one-humped camel after reflection of $\mathrm{M}$. incisivus superioris (left side). 1- M. lateralis nasi, 2- M. incisivus superioris (reflected), 3- Pars molaris of $\mathrm{M}$. buccinator, 4- M. mentalis.

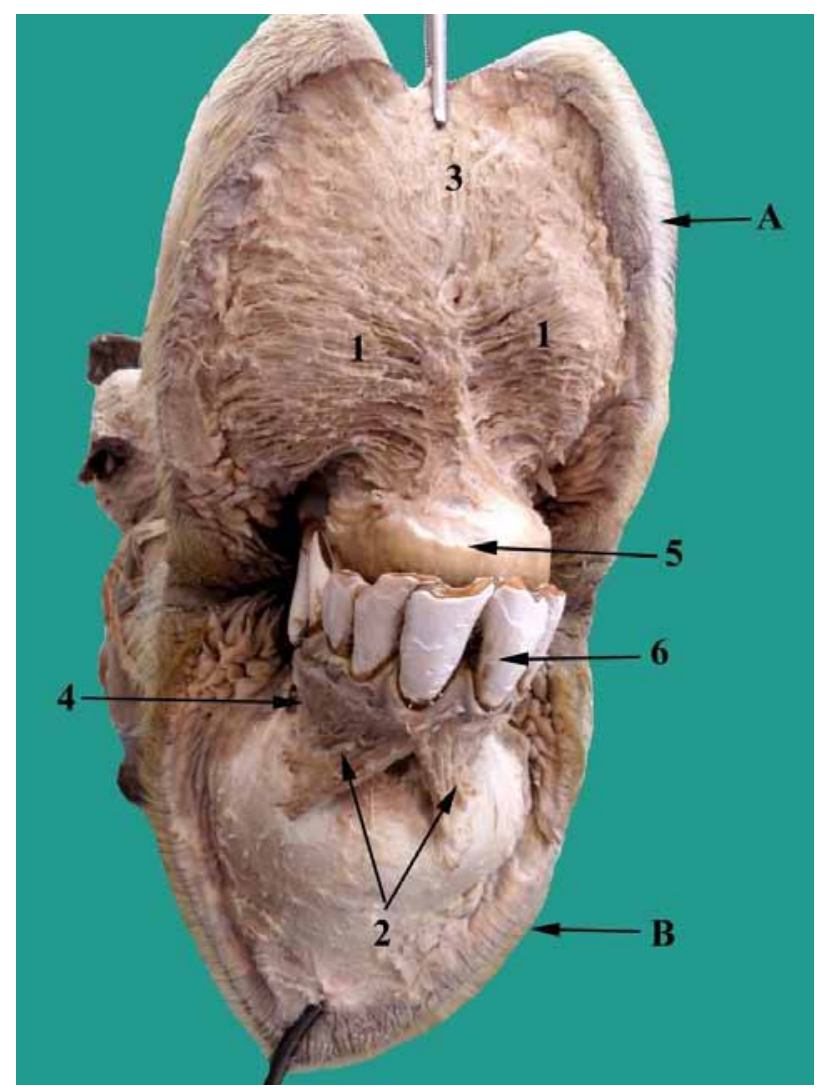

Figure 5. The upper and lower lips of the one-humped camel after removal of the mucous membrane to show the $\mathrm{Mm}$. incisivi. A- Upper lip, B- Lower lip, 1- M. incisivus superioris, 2- M. incisivus inferioris, 3- Pars labialis of M. orbicularis oris, 4- M. mentalis (origin), 5-Alveolar border of the incisive bone (dental pad), 6- Lower incisive. dorsal delicate and ventral small aponeurotic origins; the dorsal origin came from the frontal and nasal fascia (Figure 8/1), in addition to the fascia on the dorsal parietal nasal cartilage in common with the origin of $\mathrm{Mm}$. dilator naris apicalis and medialis (Figures $1 / 2,2 / \mathrm{b}$ ). The ventral aponeurotic tendon of origin came from the maxilla rostroventral to the orbit in common with the origin of M. malaris (Figure 8/2).

Moreover, the M. levator nasolabialis was directed rostroventral over the lateral aspect of the maxillary body and covered the maxillo-labial group of muscles (Figure 2/4). The nasal part of the levator nasolabial muscle terminated in the caudal aspect of the nostril and fused with those of $\mathrm{M}$. dilator naris medialis, M. caninus and M. lateralis nasi (Figure $2 / 2,3,4$ ). While, the labial part of the muscle inserted in the upper lip and merged with $\mathrm{M}$. orbicularis oris without forming a tendon at their insertion (Figure $2 / 4,5$ ). The muscle was related superficially by the skin and fascia, deeply by the $\mathrm{V}$. facialis, M. levator labii superioris, $M$. dilator naris lateralis, M. depressor labii superioris (Figure $3 / 2,3,4, \mathrm{e}$ ), N. infraorbitalis and $\mathrm{N}$. buccalis dorsalis (Figure 6/b,c,d).

The middle layer of the narial and labial muscles was formed of the maxillo-labial group of muscles which included; M. levator labii superioris, M. dilator naris lateralis, and M. depressor labii superioris.

These muscles were originated by a common tendon from an area rostro-ventral to the infraorbital foramen (Figure 8/3). The three muscles were found deep to M. levator nasolabialis and covered the branches of the infraorbital nerve beneath them.

\section{M. Levator Labii Superioris:}

The M. levator labii superioris was large, well developed and triangular in shape, sprang rostro-dorsally in a fan shape and terminated by a small tendinous sheath which was continuous with the muscle fibers of $\mathrm{Mm}$. dilator naris

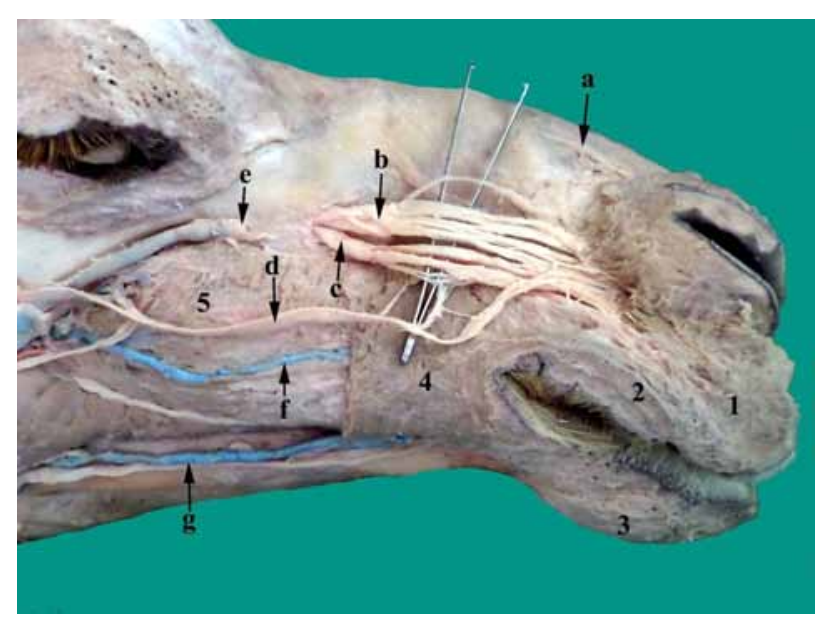

Figure 6. A Photograph showing the N. Nasalis Externus, $\mathrm{N}$. Infraorbitalis and terminal branches of the N. Buccalis Dorsalis of the one-humped camel (Right side). a- N. nasalis externus, b- R. dorsalis of N. infraorbitalis, c- R. ventralis of N. infraorbitalis, d- N. buccalis dorsalis, e- V. facialis, $\mathrm{f}-\mathrm{V}$. buccalis superficialis, g- V. labialis inferior superficialis. 1- Pars labialis of M. orbicularis oris, 2- Pars marginalis of M. orbicularis oris, 3- M. mentalis, 4- Pars buccalis of $\mathrm{M}$. buccinators, 5 - Pars molaris of M. buccinators. 


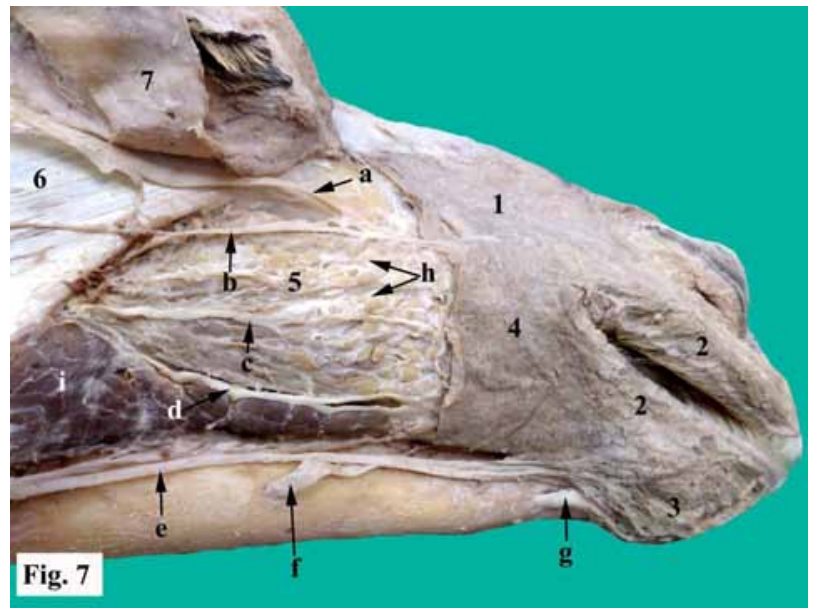

Figure 7. A Photograph showing the terminal branches N. Buccalis Dorsalis, N. Buccalis, N. Buccalis Ventralis and mental nerves of one-humped camel after removal of $\mathrm{M}$. Malaris (Right side). a- N. buccalis dorsalis, b- R. dorsalis of $\mathrm{N}$. buccalis, $\mathrm{c}-\mathrm{R}$. intermedius of $\mathrm{N}$. buccalis dorsalis, $\mathrm{d}-\mathrm{R}$. ventralis of $\mathrm{N}$. buccalis, e- N. buccalis ventralis, $\mathrm{f}-\mathrm{N}$. mentalis caudalis, g- N. mentalis rostralis, h-Dorsal and intermediate buccal glands, i- parotid gland. 1- M. levator nasolabialis, 2- M. orbicularis oris, 3- M. mentalis, 4- Pars buccalis of M. buccinators, 5- Pars molaris of M. buccinators, 6- M. masseter.

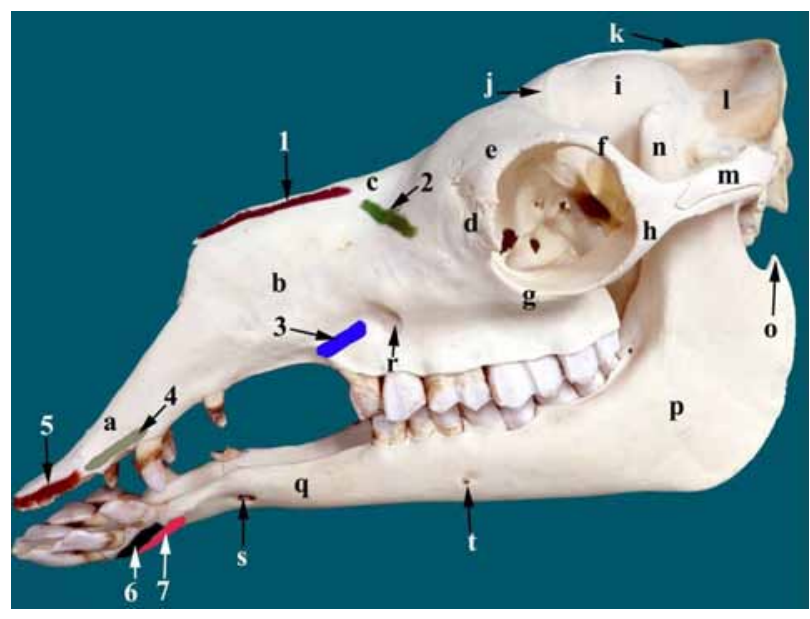

Figure 8. The lateral aspect of the skull and mandible of the one-humped camel showing the site for muscular attachment (colored) of the narial and labial muscles (Left side). a- Incisive bone, b- Maxilla, c- Nasal bone, d- Lacrimal bone, e- Frontal bone, f- Zygomatic process of frontal bone, g- Zygomatic bone, h- Zygomatic process of zygomatic bone, i- Parietal bone, j- temporal line, k- External sagittal crest, 1- Occipital bone, $\mathrm{m}$ - Zygomatic process of temporal bone, $\mathrm{n}$ - Coronoid process of mandible, o- Angular process of mandible, $\mathrm{p}$ - Ramus mandible, q- Body of mandible, r- Infraorbital foramen, s- Rostral mental foramen, t- Caudal mental foramen. 1- First dorsal origin of the M. levator nasolabialis, 2-Second ventral origin of the M. levator nasolabialis, 3-Common origin of $\mathrm{Mm}$. levator labii superioris, caninus and depressor labii superioris, 4- Origin of $\mathrm{M}$. lateralis nasi, 5- Origin of the M. incisivus superioris, 6- Origin of the $\mathrm{M}$. incisivus inferioris, 7 - Origin of the M. mentalis. apicalis and medialis and directly connected to M. orbicularis oris without forming tendons of insertion (Figure 3/2). The M. levator labii superioris was found dorsal to $M$. dilator naris lateralis, and it was related deeply to the tributaries of V. facialis (Figure $3 / \mathrm{e}$ ).

\section{M. Dilator Naris Lateralis (M. Caninus):}

The M. caninus was found between M. levator labii superioris dorsally and $\mathrm{M}$. depressor labii superioris ventrally (Figure 3/3). Its muscle fibers ran rostrally, terminated into the caudolateral aspect of the nostril and partly fused with M. levator nasolabialis and $\mathrm{m}$. lateralis nasi (Figure 2/3).

\section{M. Depressor Labii Superioris:}

The M. depressor labii superioris was found between M. dilator naris lateralis dorsally and pars buccalis of $\mathrm{M}$. buccinator ventrally (Figure 3/4). The muscle fibers were directed rostroventrally undercover of the M. levator nasolabialis and on the dorsal border of pars buccalis of $M$. buccinator (Figure $3 / 4,7$ ) and covered the terminal part of $\mathrm{N}$. buccalis dorsalis (Figure $3 / 4, \mathrm{~b}$ ). It inserted into the rostral part of the upper lip and blended with the fibers of M. orbicularis oris and M. levator nasolabialis (Figure 3/4,5).

The deep layer consisted mainly of $\mathrm{M}$. lateralis nasi.

\section{Lateralis Nasi:}

The M. lateralis nasi was well-developed and originated from the alveolar border of the incisive bone (Figure 8/4). Its muscle fibers were directed dorsally and slightly caudally to be terminated in the lateral wing of the nostril, where they continued with those of the $\mathrm{M}$. dilator naris lateralis, M. levator nasolabialis and $M$. dilator naris medialis at the caudolateral angle of the nostril (Figure 2/3). The muscle was partially overlapped by the $M$. incisivus superioris (Figure $4 / 1,2$ ).

The upper and lower lips of the one-humped camel had their musculatures were; M. Orbicularis Oris, M. Mentalis, M. Incisivus Superioris and M. Incisivus Inferioris:

\section{M. orbicularis oris:}

The M. orbicularis oris constituted incomplete sphincter of the mouth, as it was interrupted by the median labial fissure in the maxillary lip (Figure 1/c). The muscle fibers were interspersed between the skin and mucous membrane of the lips, intimately adhered to the skin with no direct attachment to the bones of the skull. The muscle was made up of labial and marginal portions; the fibers of the labial part (pars labialis) were deeply seated to those of the marginal one (Figures 2/5, 3/5). The marginal part (pars marginalis) of the muscle ran parallel to the free edges of the lips and the oral commissure, strands of connective tissue were found around the roots of tactile hair (Figures 2/6,3/6). The muscle fibers in the maxillary lip sprang dorsally and blended with the insertion of $\mathrm{Mm}$. levator nasolabialis and M. depressor labii superioris. The muscle fibers in the mandibular lip sprang ventrally and merged with the fibers of M. mentalis (Figure $7 / 2,3$ ). The thickest part of the muscle was found at the angle of the mouth where the muscle was blended with $\mathrm{M}$. buccinator with no line of demarcation (Figure 7/2,4). 


\section{M. Mentalis:}

The M. mentalis consisted of small fascicles that constituted the chin prominence. The muscle fibers originated from the body of the mandible on either side of the mandibular symphsis caudal to the origin of $\mathrm{M}$. incisivus inferioris (Figures $5 / 4$, $8 / 6)$. It spread ventrolaterally to be inserted in the skin of the chin (Figures $4 / 4,6 / 3,7 / 3$ ). It was blended dorsally with M. orbicularis oris (Figure $7 / 2,3$ ).

\section{M. Incisivus Superioris:}

The M. incisivus superioris was well developed that constituted the bulk of the maxillary lip. It was found between the fibers of the labial part of $\mathrm{M}$. orbicularis oris and the mucous membrane of the maxillary lip (Figure 5/1). The muscle fibers originated from the body of the incisive bone (Figure $8 / 5$ ), partially overlapped the origin of $M$. lateralis nasi (Figure $4 / 1,2)$. Its fibers were condensed in the midline within the labial frenulum of the maxillary lip and some fibers sprang ventrolaterally in a fan shape toward the margins of the maxillary lip (Figure 5/1).

\section{M. Incisivus Inferioris:}

The M. incisivus inferioris was less extensive than $M$. incisivus superioris, originated from the alveolar border of the incisive part of the body of the mandible (Figure 8/6), partly in common with the origin of $\mathrm{M}$. mentalis. Its fibers directed rostroventrally, diverged into two parts forming inverted $\mathrm{V}$-shape and inserted into the mandibular lip (Figure 5/2).

Nerve supply of the nostrils and lips:

The lips and nostrils of the one-humped camel were innervated by some branches from the trigeminal nerve (N. trigeminus $\mathrm{V}$ ) and the facial nerve (N. facialis VII).

1. Branches from the trigeminal nerve:

1. A. External nasal branch of ethmoidal nerve (R. Nasalis Externus of N. Ethmoidalis)

The external nasal branch was detached from the ethmoidal nerve of the ophthalmic division of the trigeminal nerve and ran rostroventrally over the dorsal parietal nasal cartilage and just dorsal to the nasal process of the incisive bone. The nerve continued rostroventrally under cover of $\mathrm{Mm}$. levator nasolabialis, dilator naris apicalis and medialis, and divided into two small branches which ramified in the dorsal and medial aspects of the nostril (Figures 3/a, 6/a).

\section{B.Infraorbital nerve (N. Infraorbitalis)}

The infraorbital nerve was the terminal branch of the maxillary division of the trigeminal nerve; it emerged from the infraorbital foramen (Figure $8 / \mathrm{r}$ ) and divided into dorsal and ventral branches which were separated by the infraorbital vein. These branches were distributed medial to the maxillo-labial group of muscles (M. levator labii superioris, M. dilator naris lateralis and M. depressor labii superioris).

1.B.a. Dorsal branch of Infraorbital nerve (R. Dorsalis of N. Infraorbitalis):
The dorsal branch of the infraorbital nerve was larger than the ventral one; it was divided into three branches immediately in front to the infraorbital foramen (Figure $6 / \mathrm{b}$ ). These branches ran rostrally under cover of $\mathrm{Mm}$. levator labii superioris and dilator naris lateralis, and they were related deep to the buccal part of $M$. buccinator. Each of these three branches was divided into many branches that united with each other and with branches from the ventral branch of the infraorbital nerve, and then it terminated into the nostril.

\section{B.b. Ventral branch of Infraorbital nerve (R. Ventralis of N. Infraorbitalis):}

The ventral branch of the infraorbital nerve was divided into two branches about $1 \mathrm{~cm}$ from the infraorbital foramen, these branches was separated from each other by the infraorbital artery. Then it directed rostrally under cover of the $\mathrm{Mm}$. dilator naris lateralis and depressor labii superioris, and it was related deep to the pars buccalis of $\mathrm{M}$. buccinator. Each of these two branches was divided into two branches which anastomosed with the branches of the dorsal branch and branches of the dorsal buccal nerve to be ramified into the nostril and maxillary lip (Figure 6/c).

\section{C. Buccal branch (N. Buccalis)}

The buccal branch of the mandibular nerve passed between the rostral border of the masseter muscle dorsally and the most caudal part of the pars molaris of the M. buccinator ventrally, where it was divided into dorsal, intermediate and ventral branches.

\section{C.a. Dorsal branch (R. Dorsalis):}

The dorsal branch of the buccal nerve appeared between the pars molaris of the M. buccinator ventrally and the rostral border of the masseter muscle caudally and it was covered by the M. depressor palpebrae inferioris (Figure $7 / \mathrm{b}$ ). Then the dorsal branch continued rostrally over the dorsal border of the M. malaris and covered by the M. zygomaticus, where it accompanied the dorsal buccal nerve. Then it ran rostrally over the dorsal border of the M. zygomaticus (Figure 3/d), and finally it ramified in the pars buccalis of the M. buccinator, the $\mathrm{M}$. orbicularis oris and the upper lip dorsal to the angle of the mouth (Figure 3/c).

\section{C.b. Intermediate branch (R. Intermedius):}

The intermediate branch of the buccal nerve of ran rostrally over the lateral aspect of the Pars molaris of the M. buccinator in common with the V. buccalis superficialis (Figure $3 / \mathrm{f}$ ). During its course, the intermediate branch gave off small branches to the buccal salivary gland and terminated in the pars buccalis of the $\mathrm{M}$. buccinator and $\mathrm{M}$. orbicularis oris at the angle of the mouth (Figure $7 / \mathrm{c}$ ).

\section{C.c. Ventral branch (R. Ventralis):}

The ventral branch of the buccal nerve directed rostroventrally between the pars molaris of the M. buccinator dorsally and the ventral buccal salivary gland ventrally (Figure $7 / \mathrm{d}$ ) in common with the deep inferior labial vein (Figure 6/g) and terminated in the lower lip. 


\section{D. Mental nerves:}

1.D.a. Caudal mental nerve (N. Mentalis Caudalis):

The caudal mental nerve was detached from the mandibulo-alveolar nerve and it was emerged from the caudal mental foramen (Figure $8 / \mathrm{t}$ ) at the middle of the body of the mandible. This nerve passed rostrally to join the ventral buccal nerve and they gave small branches to the caudal part of the lower lip (Figure 7/f).

\section{D.b. Rostral Mental nerve (N. Mentalis Rostralis):}

The mental nerve was the terminal branch of the mandibulo-alveolar nerve which was emerged from the rostral mental foramen (Figure 8/s). It was distributed in a tree-like manner (rami labialis mandibularis) in the rostral and ventral parts of the lower lip and chin (Figure $7 / \mathrm{g}$ ).

\section{Branches from the facial nerve}

\section{A. Terminal branches of the dorsal buccal nerve:}

The dorsal buccal nerve of the facial nerve terminated deep to the M. levator nasolabialis (Figure 7/a) and M. depressor labii superioris (Figure $3 / \mathrm{b}$ ) and it was divided into three branches which anastomosed with branches of the infraorbital nerve to supply the Mm. levator nasolabialis, depressor labii superioris, dilator naris lateralis, buccinator, and orbicularis oris. Finally, it terminated in the mucous membrane and skin of the upper lip (Figure 6/d).

\section{B. terminal branches of the ventral buccal nerve}

At the middle of the body of the mandible, the ventral buccal nerve joined the caudal mental nerve and they gave small branches to the lower lip (Figure 7/e).

\section{Discussion}

The nostrils of the camel were slit-like orifice that was also observed by (BADAWI and FATEH EL-BAB, 1974; ESHRA and BADAWY, 2014) in the same animal. According to (HAFEZ, 1968; SMUTS and BEZUIDENHOUT, 1987) the natural closure of this slit-like orifice in camel was usually associated with the presence of the sphincteric muscles and the arrangement of the muscles in such a way that the sphincter formed enable the nostrils to be closed. Moreover, Hafez (1968) added that the sphincteric muscles keep the nostril closed most of the time, thus reducing evaporation from the nose and preventing the entrance of sand and flies. Moreover, Eshra and Badawy (2014); Mugerwa (1981) in camel and Frey and Hofmann (1997) in Saiga antelope stated that the camel and Siaga antelope are forced to close their nostrils during sand storm. In addition to that the attachment of the M. orbicularis oris with the M. levator nasolabialis and M. levator labii superioris may help in the closure of the camel nostril (ESHRA and BADAWY, 2014).

The dissection of the nostrils and lips of the one-humped camel in the present study was in accordance with Smuts and Bezuidenhout (1987) in the same animal who stated that the muscles of the nostrils and lips included; M. dilator naris apicalis, M. dilator naris medialis, M. levator nasolabialis, M. levator labii superioris, M. dilator naris lateralis, M. depressor labii superioris, M. orbicularis oris, M. incisivus superioris,
M. incisivus inferioris, and M. mentalis in the same animal. There was no evidence for the presence of $\mathrm{M}$. depressor labii inferioris in camel and this was confirmed by the same findings that were reported by Khidr (1978) and Smuts and Bezuidenhout (1987) in the same animal.

Regarding the Mm. dilator naris apicalis and medialis of one-humped camel, they were originated by a common tendon from the fascia covering the dorsal parietal nasal cartilage. The same results were observed by Smuts and Bezuidenhout (1987) in the same animal. While, the M. dilator naris apicalis of sheep (MAY, 1970); ruminants (GETTY, 1975); buffalo (ABD EL-MOEIN, 1990); and horse (SISSON, 1975) was represented by two layers originated from the dorsal surface of the incisive bone. Meanwhile the M. dilator naris medialis of ox (GETTY, 1975) constituted the dorsal part of M. lateralis nasi.

The current study in agreement with by Smuts and Bezuidenhout (1987) in camel, (MAY, 1970) in sheep and (SISSON, 1975) in horse revealed that the M. levator nasolabialis was represented by a single muscular layer. The latter author added that the M. levator nasolabialis of horse was divided into dorsal and ventral parts through which the M. caninus passed. On the other hand, Eshra and Badawy (2014) in camel, Getty (1975) in ox, Saber (1987) in goat and Abd El-Moein (1990) in buffalo observed that the M. levator nasolabialis was divided into superficial and deep muscular layers.

Concerning the M. levator labii superioris in camel, it was named M. levator labii maxillaris by Eshra and Badawy (2014) in the same animal. It was observed that this muscle in camel was well-developed muscle layer that terminated by a small tendinous sheath which was continuous with the muscle fibers of $\mathrm{Mm}$. dilator naris apicalis and medialis and directly connected to the M. orbicularis oris. These observations were in contrast with Eshra and Badawy (2014) in the same animal who reported that the muscle fibers of the M. levator labii superioris was blended with that of the M. levator nasolabialis and M. orbicularis oris. Moreover, in ox (GETTY, 1975); buffalo (ABD EL-MOEIN, 1990) and horse (SISSON, 1975) reported that this muscle was well-developed and united with its fellow of the opposite side to form one band that terminated in the maxillary lip. However, the M. levator labii superioris terminated by numerous bands in the maxillary lip in sheep (MAY, 1970) and in goat (SABER, 1987). This was in contrast with the observations reported by Smuts and Bezuidenhout (1987) in camel who considered this muscle as rudimentary muscle layer which fanned out in dorsal direction.

In accordance with Smuts and Bezuidenhout (1987) in camel and May (1970) in sheep and goat, the M. dilator naris lateralis was found between the M. levator labii superioris dorsally and M. depressor labii superioris ventrally and terminated in the caudolateral aspect of the nostril. Meanwhile, the $\mathrm{M}$. caninus was found between superficial and deep layers of the M. levator nasolabialis in ox (GETTY, 1975) and buffalo (ABD EL-MOEIN, 1990), while it passed between the dorsal and ventral branches of the M. levator nasolabialis in horse (SISSON, 1975). Moreover, the M. caninus terminated in the lateral angle of the nostril by one tendon in sheep [19], two or three tendons in ruminants (GETTY, 1975) and two tendons in buffalo (ABD EL-MOEIN, 1990). However, the M. caninus of goat (SABER, 1987) was represented by two muscle layers each one terminated by a thin tendon in the lateral wall of the nostril. 
In agreement with Eshra and Badawy (2014) and Smuts and Bezuidenhout (1987) the M. depressor labii superioris of camel was small muscle terminated in the most rostral part of the upper lip, the latter author named it as M. depressor labii maxillaris. However, the muscle in sheep (MAY, 1970); ruminants (GETTY, 1975); goat (SABER, 1987) and buffalo (ABD EL-MOEIN, 1990) terminated in the upper lip by dorsal and ventral tendons, both of them ended in the upper lip in sheep (MAY, 1970; NICKEL, SCHUMMER and SEIFERL, 1985), while the dorsal tendon ended in ventral portion of the nostril and the ventral one ended in the upper lip in ruminants (GETTY, 1975) and goat (SABER, 1987), however in buffalo (ABD EL-MOEIN, 1990) the dorsal tendon ended in the upper lip and the ventral one passed through the M. orbicularis oris to meet its fellow of the opposite side.

The present study observed that the M. lateralis nasi of camel was well-developed extended from the incisive bone to the nostril. Similar results were reported by Smuts and Bezuidenhout (1987) in the same animal. Meanwhile, the M. lateralis nasi of ox (GETTY, 1975) and horse (SISSON, 1975 ) consisted of dorsal and ventral parts. This muscle was absent in sheep (ESHRA and BADAWY, 2014).

In camel the $\mathrm{M}$. orbicularis oris didn't form a complete ring around the lips where its muscle fibers were interrupted by a deep philtrum that was represented by the median labial fissure in the upper lip. Such observations were reported by (KHIDR, 1978; ALI MA KHIDR and EL-HAGRI, 1979) in the same animal and (SABER, 1987) in goat. While, the M. orbicularis oris formed a complete ring around the lips in sheep (MAY, 1970). Moreover, the M. orbicularis oris consisted of marginal and labial parts in accordance with May (1970) in sheep, Getty (1975) in ruminants, Saber (1987) in goat and Sisson (1975) in horse.

In agreement with Khidr (1978); Ali Ma Khidr and El-Hagri (1979) in camel, the M. orbicularis oris had no bony attachment but it was blended with the muscles which converged on the lips.

The camel's upper lip was split at the centre by the median labial fissure, this feature thought to mean it is prehensile and has adapted to seize and grasp to aid in consumption of thorny plant material, while the lower lip is prehensile to a lower extent and tends to be pendulous in older camels. The upper lip is also sensitive enough to pick up small pieces of vegetation (HAFEZ, 1968).

Regarding the M. incisivus superioris in camel, it was well-developed and formed the bulk of the upper lip. Similar results were reported by Smuts and Bezuidenhout (1987) in the same animal. While, in ruminants (GETTY, 1975) and goat (SABER, 1987) this muscle was poorly developed.

The present study revealed that the $M$. incisivus inferioris of camel originated from the alveolar border of the body of the mandible and inserted into the lower lip. These results were agreed with Smuts and Bezuidenhout (1987) in the same animal. Moreover, this muscle formed inverted V-shape and continued caudally with the origin of the M. mentalis.

In the current study, clear and detailed dissection of the nerves that supplied the lips and nostrils in one humped camel took place and it was detected that nerve supply of these regions came mainly from branches of the Trigeminal and Facial nerves.

The external nasal branch was detached from the ethmoidal nerve of the ophthalmic division of the trigeminal nerve and ramified into the nostrils; same results were reported by Cui, Wang and Xie (2004) in camel and El-Mahdy (1985) in buffaloes.

The infraorbital nerve in the present study was divided into two branches; R. dorsalis and R. ventralis. Such observations were recorded by El-Shaieb, Hifny and Misk (1978) and Khidr (1978) in camel. These observations were in contrast with Tayeb (1951) and Zabady and El-Nady (2004) in camel who reported that the infraorbital nerve was divided into three branches which were the external nasal, internal nasal and maxillary labial nerves.

In accordance with Smuts and Bezuidenhout (1987) in camel, the ventral branch of the infraorbital nerve communicated with the terminal branch of the dorsal buccal nerve of the facial nerve.

In camel the buccal nerve of the mandibular was divided into three branches; Rr. dorsalis, intermedius and ventralis. Similar observations were recorded by Khidr (1978) in the same animal.

The present work revealed that the dorsal branch of the dorsal buccal nerve in camel was communicated with the dorsal buccal nerve. Similar communication was detected in ox and horse (GODINHO and GETTY, 1975). While the same author in goat found that the buccal nerve communicated with both dorsal and ventral buccal ones. Moreover, it communicated with the mandibulo-alveolar and lingual branches of the mandibular nerves in ox (LE ROUX, 1969).

In agreement with Arnautovic, Abu Sineina, Stanić et al. (1970) and Badawi and El-Shaieb (1975) in camel the rostral and caudal mental nerves were detached from the mandibuloalveolar nerve and ramified in the lower lip and chin.

In agreement with Arnautovic, Abu Sineina, Stanić et al. (1970) and El-Shaieb (1979) in camel the dorsal buccal nerve of the facial passed under the cover of Mm. levator nasolabialis and depressor labii superioris where it was divided into several branches that communicated with those of the ventral branch of the infraorbital nerve and finally distributed in the upper lip.

According to El-Shaieb (1979) and Tayeb (1951) in camel the ventral buccal nerve of the facial joined the caudal mental nerve at the middle of the body of mandible forming an extensive plexus that ramified in the lower lip and chin.

\section{Conclusion}

The arrangement of the narial and labial musclulatures in camel is unique and may relate to its living conditions of frequent sand-storms and direct sun rays, where it is the only domesticated animal known for its ability to close its nostril.

\section{References}

ABD EL-MOEIN, ZMS. Some topographic anatomical studies on the face region of the water buffalo in Egypt (Bos bubalis L.). Egypt: Cairo University; 1990. [Thesis].

AHMAD, S., YAQOOP, M., HASHMI, M., AHMAD, S., ZAMAN, MA. and TARIQ, M. The economic importance of camel: a unique alternative under crisis. Park Veterinary Journal, 2010, vol. 30, n. 4, p. 191-197.

ALI MA KHIDR, IMS. and EL-HAGRI, MAA. Myology of the face region of the one-humped camel (Camelus dromedarius). Zagazig Veterinary Journal, 1979, vol. 2, p. 151-160. 
ARNAUTOVIC, I., ABU SINEINA, ME., STANIC, M., ABU SINEINA, ME. and STANIC, M. The course and branches of the facial nerve of the one humped camel. Journal of Anatomy, 1970, vol. 106, n. 2, p. 341-348. PMid:5442227.

BADAWI, H. and EL-SHAIEB, M. Anatomical studies on the N. mandibularis of caprine and Camelus dromedarius in Egypt. Assiut Veterinary Medical Journal, 1975, vol. 11, no. 3-4, p. 3-17.

BADAWI, H. and FATEH EL-BAB, MR. Anatomical and histological studies on the nasal cavity of the camel (Camelusdromedarius). Assiut Veterinary Medical Journal, 1974, vol. I, p. 1-14.

CUI, S., WANG, JH. and XIE, ZM. WANG, J.H. and XIE, ZM. The nervous supply to the nasal cavity of the bacterian camel (Camelus bacterianus). Veterinary Research Communications, 2004, vol. 28, n. 1, p. 1-5. PMid:14989357. http://dx.doi.org/10.1023/ B:VERC.0000009533.92830.15.

EL-MAHDY, TOM. Some anatomical studies on the trigeminal nerve of the buffalo in Egypt. Egypt: Cairo University; 1985.

EL-SHAIEB, M. Anatomical studies on the N. facialis of Camelus dromedarius. Assiut Veterinary Medical Journal, 1979, vol. 6, n. 11-12, p. 14-27.

EL-SHAIEB, M., HIFNY, A. and MISK, NA. Anatomical studies of the N.maxillaris of the one-humped camel (camelus dromedarius) with special reference to its blockage. Assiut Veterinary Medical Journal, 1978, vol. 5, n. 9-10, p. 12-27.

ESHRA, E.A. and BADAWY, AM. Paeculiarities of the camel and sheep narial musculature in relation to the clinical value and the mechanism of narial closure. Indian Journal of Veterinary Anatomy, 2014, vol. 6, n. 1, p. 10-13.

FREY, R. and HOFMANN, RR. Skull, proboscis musculature and preorbital gland in the Saiga antelope and Guenthe, dik-dik (mammalian, Artiodactyla, Bovidae). Zoologischer Anzeiger, 1997, vol. 235, p. 183-199.

GETTY, R. Ruminant myology. In SISSON, S. Sisson and Grossman's, the anatomy of the domestic animals. 5th ed. Philadelphia: W.B. Saunders; 1975. p. 791-798.

GODINHO, HP. and GETTY, R. Cranial nerves. In GETTY, R. The anatomy of the domestic animals. 5 th ed. Philadelphia: W.B. Saunders; 1975 , p. 650-664, 1081-1091.

HAFEZ, ESE. Adaptation of domestic animals. Philadelphia: Lea and Febiger; 1968. 415 p.

HILDEBRAND, M. Anatomical preparations. Berkeley: University of California Press; 1968. p. 7-10.
INTERNATIONAL COMMITTEE ON VETERINARY GROSS ANATOMICAL NOMENCLATURE - ICVGAN. Nomina Anatomica Veterinaria. 5th ed. Hannover: Editorial Committee; 2012.

KHIDR, IMS. Myology, innervation and vascularization of the face region of the one-humped camel (Camelusdromedarius). Egypt: Zagazig University; 1978. [Thesis].

LE ROUX, JM. Certain aspects of the facial and trigeminal nerves of the ox (Bos Taurus L.). The Onderstepoort Journal of Veterinary Research, 1969, vol. 36, n. 2, p. 303-320. PMid:5407590.

MAY, NDS. The anatomy of sheep. 3rd ed. Brisbane: University of Queensland Press; 1970. p. 133-170.

MONFARED AL. Applied anatomy of the head regions of the Onehumped camel (Camelus dromedarius) and its clinical implications during regional anesthesia. Global Veterinaria, 2013, vol. 10, n. 3, p. 322-326. http://dx.doi.org/10.5829/idosi.gv.2013.10.3.72128.

MUGERWA, EM. The camel (Camelus dromedarius): a bibliographical review. Addis Ababa: International Livestock Centre for Africa; 1981. p. 33.

NICKEL, R., SCHUMMER, A. and SEIFERL, E. The locomotor system of the domestic mammals. 5th ed. Berlin: Verlag Paul Parey; 1985. p. 247-250.

OUAJD, S. and KAMEL, B. Physiological particularities of dromedary (Camelus dromedarius) and experimental implications. Science and Journal of laboratory. Animal Science, 2009, vol. 36, n. 1, p. 19-29.

SABER, AS. The musculature of the head of dik-dik (Madqua guentheri smithi) and goat (Capra hericus). Assiut Veterinary Medical Journal, 1987, vol. 19, n. 37, p. 1-8.

SADEGH, BA., SHADKHAST, M., SHARIFI, S. and MOHAMMADINA, A. Lacrimal apparatus system in one-humped camel of Iran (Camelus dromedarius): Anatomical and radiological study. Iranian Journal of Veterinary Surgery, 2007, vol. 2, n. 5, p. 76-80.

SISSON, S. Equine mycology. In GETTY, R. The anatomy of the domestic animals. 5th ed. Philadelphia: W.B. Saunders; 1975. p. 376-381.

SMUTS, MMS. and BEZUIDENHOUT, AJ. Anatomy of the dromedary. Oxford: Clarendon Press; 1987. p. 59-62.

TAYEB, MAF. The cranial nerves of camel. Egyptian Veterinary Medical Journal, 1951, vol. 4, n. 4, p. 171-182.

ZABADY, MK. and EL-NADY, F. Perineural anaesthesia of the head of camel (Camelus dromedarius). Journal of Egyptian Veterinary Association, 2004, vol. 64, n. 4, p. 409-420.

Received October 15, 2015 Accepted November 7, 2016 